\title{
COVID-19: Medical versus Religious Perspective
}

\author{
Md. Nurul Amin
}

At the end of 2019, a series of pneumonia cases of unknown cause emerged in Wuhan (Hubei, China) ${ }^{1} \mathrm{~A}$ few weeks later, in January 2020, deep sequencing analysis from lower respiratory tract samples from the infected cases identified a novel virus, severe acute respiratory syndrome coronavirus 2 (SARSCoV-2) as causative agent for that observed pneumonia cluster. ${ }^{2}$ Due to severity of this outbreak and the potential of spreading on an international scale, the World Health Organization (WHO) declared it a global health emergency on 31 January 2020. On February $11^{\text {th }}, 2020$, the WHO named the disease as coronavirus disease 2019 (COVID-19), and by March $11^{\text {th }}, 2020$ when the number of countries involved was 114 , with more than 118,000 cases and over 4000 deaths, the WHO declared it a pandemic situation. ${ }^{3}$

Newly evolved CoV-2 has posed a high threat to global public health and has been reported to reach in all continents except Antarctica. The pandemic, as of 8 February 2021, has caused 106,715,888 confirmed (COVID-19) cases and 2,328,065 COVID19-related deaths worldwide with United States being the hardest hit country. ${ }^{4}$ The current emergence of COVID-19 is the third CoV outbreak in humans over the past 2 decades. ${ }^{5}$ The previous two outbreaks were severe acute respiratory syndrome (SARS) and the Middle East respiratory syndrome (MERS) that emerged in 2002 and 2012 in East Asia and the Middle East respectively. At the beginning, China experienced the majority of the burden associated with COVID-19 in the form of disease morbidity and mortality, ${ }^{6}$ but over time the disease menace moved to Europe, particularly Italy, Spain, UK and then to the United States. The COVID-19 pandemic has led to an untold loss of human life worldwide and presents an unprecedented challenge to public health, food systems and the world economy. It is far more than a health crisis-affecting societies and economies at their core. The pandemic caused the largest global recession in the history due to sudden interruption of global trade and supply chains that led to significant economic losses. ${ }^{7}$ Tens of millions of people are at risk of falling into extreme poverty with consequent malnutrition and associated nutritional deficiency diseases. ${ }^{8}$ The recent increase in the number of critically ill patients with COVID-19 has already surpassed the intensive care supplies, limiting intensive care services to only a small portion of them, ${ }^{9}$ which might also have contributed to the increased case fatality rate observed in the COVID-19 outbreak.

The outbreak has not yet been controlled, although extensive efforts are being put in place to counter this virus. ${ }^{10}$ Presently, we are not in a position to effectively treat COVID-19, since neither approved vaccines nor specific antiviral drugs for treating human CoV infections are available. ${ }^{11-13}$ Some therapeutic options for treating COVID-19 showed efficacy in vitro studies; however, to date, these treatments have not undergone any randomized animal or human clinical trials, which limit their practical applicability in the current pandemic. ${ }^{11,13,14-16}$ Most nations are currentlymaking efforts to prevent further spread of this potentially deadly virus by implementing preventive and control strategies (sanitary measures, social distancing and lockdown). This unpredictable, fast spreading infectious disease has been causing universal awareness, anxiety and distress. ${ }^{17}$

The primary cluster of patients of COVID-19 was found to be connected with the Huanan South China Seafood Market in Wuhan. ${ }^{18}$ It is no coincidence that Fan et al. predicted potential SARS- or MERS-like

\section{Authour's information: \\ ${ }^{1}$ Dr. Md. Nurul Amin, Associate Professor (Research \& Development) \& Executive Editor (Ibrahim Cardiac Medical Journal), Ibrahim Cardiac Hospital \& Research Institute, Shahbag, Dhaka, Bangladesh.}

Correspondence :Dr.Md. Nurul Amin, Mobile:01753178452, E-mail:mdamin01@yahoo.com 
CoV outbreaks in China following pathogen transmission from bats. ${ }^{19}$ Phylogenetic analyses have revealed that SARS-CoV-2 is closely related ( $88 \%$ similarity) to two SARS-like CoVs derived from bat SARS-like CoVs (bat-SL-CoVZC45 and bat-SLCoVZXC21) indicating a common origin. Furthermore, SARS-CoV-2 is genetically distinct from SARS-CoV (79\% similarity) and MERS-CoV (nearly 50\%). ${ }^{20}$ However, particular pieces of evidence based on further complete genomic analysis of current isolates are necessary to draw any conclusions. Their possible ancestor was hypothesized to be from bat CoV strains, wherein bats might have played a crucial role in harboring this class of viruses. Advanced studies using Bayesian phylogeographic reconstruction identified the most probable origin of SARS-CoV-2 as the bat SARS-like coronavirus, circulating in the Rhinolophus bat family. ${ }^{21}$

Identifying the origin of SARS-CoV-2 and the pathogen's evolution will be helpful for disease surveillance, ${ }^{22}$ development of new targeted drugs, and prevention of further epidemics. ${ }^{23}$ The possible origin of SARS-CoV-2 and the first mode of disease transmission are not yet identified. ${ }^{24}$ Analysis of the initial cluster of infections suggests that the infected individuals had a common exposure point, a seafood market in Wuhan, Hubei Province, China. The restaurants of this market are well-known for providing different types of wild animals for human consumption. ${ }^{25}$ The SARS-CoV-2 has been alleged to have originated from an animal host (zoonotic origin) with further human-to-human transmission. The Huanan South China Seafood Market also sells live animals, such as poultry, bats, snakes, and marmots. ${ }^{26}$ This might be the point where zoonotic (animal-to-human) transmission occurred. ${ }^{25}$ This is not the first time where the culinary practices of China have been blamed for the origin of novel coronavirus infection in humans. Previously, the animals present in the live-animal market were identified to be the intermediate hosts of the SARS outbreak in China. ${ }^{27}$ Several wildlife species were found to harbor potentially evolving coronavirus strains that can overcome the species barrier. ${ }^{28}$
In the face of widespread criticism and probable zoonotic spillover of COVID-19, China imposed a temporary ban in January 2020 on the sale of live-dead animals in wet markets. However, now hundreds of such wet markets have been reopened without optimizing standard food safety and sanitation practices. ${ }^{29}$ People are buying bats, dogs, cats, birds, scorpions, badgers, rabbits, pangolins (scaly ant eaters), minks, soup from palm civet, ostriches, hamsters, snapping turtles, ducks, fish, Siamese crocodiles, and other animal meats without any fear of COVID-19. The Chinese government is encouraging people to feel they can return to normalcy. However, this could be a risk, as it has been mentioned in advisories that people should avoid contact with live-dead animals as much as possible, as SARS-CoV-2 has shown zoonotic spillover. Additionally, we cannot rule out the possibility of new mutations in the same virus being closely related to contact with both animals and humans at the market. ${ }^{30}$

Wet markets of live-dead animals do not maintain strict food hygienic practices. Fresh blood splashes are present everywhere, on the floor and tabletops, and such food customs could encourage many pathogens to adapt, mutate, and jump the species barrier. There is an urgent need for a rational international campaign against the unhealthy food practices of China to encourage the sellers to increase hygienic food practices or close the crude live-dead animal wet markets. There is a need to modify food policies at national and international levels to avoid further life threats and economic consequences from any emerging or reemerging pandemic due to close animal-human interaction. ${ }^{31}$

Strategies to identify cases and limit spread by widespread testing and physical distancing have been challenging to implement. Healthcare and public health systems have been overwhelmed, resulting in continued escalation in many countries and profound effects on lives and livelihoods. As asymptomatic cases or cases with mild infection are suspected of transmitting infections, they further add to the complexity of disease transmission dynamics in COVID-19 infections. ${ }^{32}$ The urgent need 
for effective SARS-CoV-2 vaccines cannot be overstated. Immunization cannot only protect individuals but also, if provided to a substantial proportion of popuation in a timely way, even partially protective vaccines may induce sufficient herd immunity to curtail the spread of this virus and reduce morbidity and mortality across the globe.

As vaccines are widely considered as part of the exit strategy to enable people to return to normalacy, a range of vaccine design approaches and platforms have been employed. Researchers around the world are aggressively working round the clock to develop a vaccine against COVID-19, mostly by targeting the spike glycoprotein. Pre-clinical evaluation of candidate vaccines is a prerequisite to initiating clinical trials. Vaccines are usually first evaluated in a pre-clinical phase using either human/mammalian cell cultures (in vitro) or appropriate animal models (in vivo). In the case of positive results in the pre-clinical phase, vaccine candidates proceed through testing over three clinical trial phases to determine whether they are safe and effective in humans. On average, the probability of a vaccine entering the market, taken from the pre-clinical phase through clinical testing and licensure, is below $10 \% .^{33}$ Since the global impact of COVID-19 is unprecedented in the modern era, the development and testing of a new vaccine are being expedited. Trials are now being conducted at "pandemic speed"34 and using novel designs to develop a SARS-CoV-2 vaccine for worldwide distribution in an unparalleled timeframe to vaccinate the world's population. Since > $90 \%$ of candidate vaccines typically fail and the frequent mutation of the SARS-CoV-2, the prospect of a successful vaccine in near future is very limited. Besides, owing to extensive diversity in antigenic variants, cross-protection rendered by the vaccines is significantly limited, even within the strains of a phylogenetic sub-cluster. ${ }^{35}$ Even though the more vulnerable group of the population, such as the elderly, immunocompromised, and those with co-morbidities, would have been given priority for vaccines, they had not been included in clinical trials conducted so far and thus the effectiveness of the vaccine and risk of side-effects is questionable in this population.

Given the high-level of attrition during vaccine development and the lack of effective antiviral therapy, we need to depend solely on implementing effective infection control measures to lessen the risk of possible nosocomial transmission. ${ }^{36}$ We have to reliy on the social distancing and hygiene precautions and, if necessary, rigorously enforce them so as to control the pandemic. Hopefully, similar to previous outbreaks, the current outbreak also will be contained shortly and people will return to their normal life. But is there any gurantee that no Corna virus outbreak or any other even deadly infectious disease will not occur in future. The possibility of another outbreak cannot be ruled out, as predicted by Fan et al(Fig. 1). ${ }^{19}$ Indeed, the present outbreak caused by SARS-CoV-2 (COVID-19) was expected. Had the Chinese people's food behavior been shaped by religious restrictions (laid down in Islam), they would not have come in close contact with the natural host of CoV (bat) or most of its intermediate hosts and perhaps the world people today would not have faced so fatal a situation. Then, the real issue is how we are planning to counter the next zoonotic CoV epidemic that is likely to occur within the next 5 to 10 years or even sooner(Fig. 1).

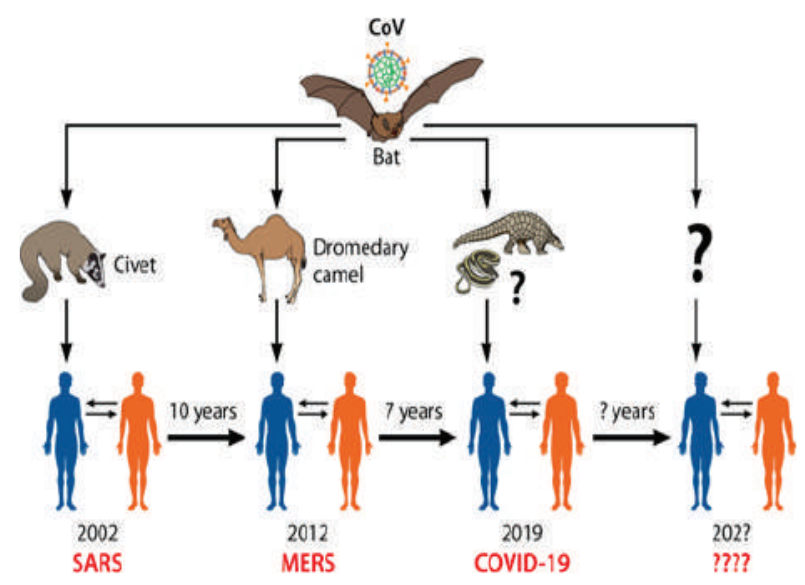

Fig.1: Coronavirus origins. Coronavirus is the most prominent example of an emerging virus that has crossed the species barrier from wild animals to humans, like SARS and MERS. The origin of SARS-CoV-2 is also suspected to be from an intermediate animal host. The possibility of crossing the species barrier again for the fourth time cannot be ruled out. 
The present activities of the world people concerning COVID-19 pandemic suggest that they are all moving in the same direction, that is, to find an ideal treatment for the COVID-19 and an effective and safe vaccine to prevent it. Whenever an epidemic/ pandemic shakes the world, it is the usual way of finding a solution. Very few people think of why it has occurred and created so devastating a situation and how its future occurance could be prevented. In particular, people rarely think or try to find a solution of pandemics from their religion, although every major religion has laid down clear instructions about it. The present context of COVID-19, where all measures have failed to contain the disease, demands a comprehensive discussion of what views our religion hold about its occurance and what remedy it suggests about prevention and control of the ongoing pandemic. Human history shows that people have to face several epidemic/pandemics hitherto since their jouney started on this earth. If we look at some of these epidemics, famous in history (Table I), it will be an inspiration to guide ourselves towards better action to prevent or control future happening of SARS-CoV diseases or likes.

\section{Table I. Table I. Some Famous Epidemics in History ${ }^{37}$}

\begin{tabular}{|c|c|c|c|}
\hline $\begin{array}{l}\text { Epidemic/ } \\
\text { Pandemic }\end{array}$ & Place & Year & $\begin{array}{c}\text { Death } \\
\text { (In million) }\end{array}$ \\
\hline $\begin{array}{l}\text { Black Death } \\
\text { (Great Plague } \\
\text { of Europe) }\end{array}$ & $\begin{array}{l}\text { Europe, Asia \& } \\
\text { North Africa }\end{array}$ & $1346-1353$ & $75-200$ \\
\hline Spanish flu & Worldwide & $1918-1920$ & $17-100$ \\
\hline $\begin{array}{l}\text { Plague of } \\
\text { Justinian }\end{array}$ & Europe \& West Asia & $541-542$ & $15-100$ \\
\hline $\begin{array}{l}3^{\text {rd }} \text { Plague } \\
\text { pandemic }\end{array}$ & Whole World & $1855-1960$ & $12+$ \\
\hline $\begin{array}{l}\text { Cocoliztli } \\
\text { Epidemic }\end{array}$ & Mexico & $1545-1548$ & $5-15$ \\
\hline $\begin{array}{l}\text { HIV/AIDS } \\
\text { pandemic }\end{array}$ & Worldwide & $\begin{array}{r}\text { 1981-Till } \\
\text { date }\end{array}$ & $35+$ \\
\hline $\begin{array}{l}\text { Antonine } \\
\text { Plague }\end{array}$ & Roman Empire & $165-180$ & $5-10$ \\
\hline $\begin{array}{l}\text { Mexico } \\
\text { Smallpox }\end{array}$ & Mexico & $1519-1520$ & $5-8$ \\
\hline $\begin{array}{l}\text { COVID-19 } \\
\text { pandemic }\end{array}$ & Worldwide & $\begin{array}{r}\text { As of } \\
7 \text { Feb } 2021\end{array}$ & 2.33 \\
\hline
\end{tabular}

One thing to note here is that none of these epidemics, which have been happening for thousands of years, have rarely spread and caused a devastating situation to any town where people have led their lives in remembrance of Allah or the Creator. On the contrary, it has originated and spread from all such towns where people have engaged in disobedience to Allah and have gone to extreme lengths to oppose Him, as is evident from the sayings of religious scriptures. For the sake of the believers, Allah says: "If you don't go forth to fight against the ungodly and the unjust in society, He will punish you with a painful torment and will replace you with another nation. And you will not harm Him in the least. And Allah has power over all things" (Qur'an 9:38-39). We shall certainly test you with fear \& hunger \& loss of property, life \& crops. But [Prophet], give good news to those who are steadfast" (Qur'an 2:155). The Prophet (Sm) says, "I swear by Allah, (who controls my life) you must enjoin what is right and forbid what is wrong. Otherwise, the punishment of Allah will soon descend upon you. Then you will keep on praying (to get rid of it) but your prayers will not be accepted" (Sunan-e-Tirmizi: 2169). Indeed, mankind is not getting rid of this virus even after using all their strengths. They are praying to Allah to get rid of the COVID-19, but probably Allah is not accepting their prayer. The present scenario of COVID-19, rather suggests $\mathrm{He}$ is increasing the intensity of torment even more than before. Prophet Mohammad (Sm) says, "If a person commits a sin and the people of that nation don't restrain him from it despite their strength, Allah will inflict a terrible punishment on that nation before death" (Saheeh Abudaud:1554, 4339).

Narrated Usama bin Zaid: Allah's Apostle said, Plague was a means of torture sent on a group of Israelis (or on some people before you). So, if you hear of its spread in a land, don't approach it, and if a plague should appear in a land where you are present, then don't leave that land in order to run away from it (Bukhari, 3473). Why the plague spread out? The answer of this question is given in various hadiths. Narrated by Hazrat Abdullah ibni Umar that Prophet Mohammad (pbuh) said "Whenever obscenity would prevail rampantly in a society/ country and people would do it commonly than the plague and other unknown diseases will 
spread that had not been found of your grandparent's times and not even before" (Majah, 4019). Review of the Holy Qur'an and Sunnah shows that the real causes of torment are human crimes which occur in three stages-at 1) Personal Level, 2) Social Level and 3) State Level. ${ }^{38}$

Allah has created mankind as the best creature of all His creations. As a creator, he loves people. But if man transgresses the limits, goes against the law of Allah, engages in acts contrary to conscience, takes part in immoral acts, partakes in terrorism and unjust killing, then the Creator is patient and after reaching the final limit, inflicts various diseases and gives punishments. COVID-19 pandemic is undoubtedly a part of them. The whole world is helpless today. No one knows when it will end. There is no alternative to medical measure to control the ongoing pandemic. But it is not the panacea. Medical measure will work if Allah wants it to work. So along with medical measures, we must follow what our religion has instructed us to follow. That is, Muslims should seek the help of Allah and follow the path of the Holy Qur'an and Sunnah. Similarly, non-Muslims should follow their respective religions. All Muslims and non-Muslims should refrain themselves from unjust, obscene and immoral acts and stay free from conflicts. Only then can we hope that Allah will save mankind from this deadly disease. If Allah doesn't want to protect us from this disease, then, there is no power in the world that can save us from the menace.

\section{REFERENCES:}

1. Lu H, Stratton CW, Tang YW. Outbreak of pneumonia of unknown etiology in Wuhan, China: The mystery and the miracle. J Med Virol 2020;92:401-402. doi: 10.1002/jmv.25678.

2. Huang C, Wang Y, Li Z, Ren L, Zhao J, Hu Y, et al. Clinical features of patients infected with 2019 novel coronavirus in Wuhan, China. Lancet. 2020;395:497-506. doi: 10.1016/S0140-6736(20)30183-5.

3. World Health Organization Director-General's Opening Remarks at the Media Briefing on COVID-19-11 March 2020. accessed on 11 March 2020; Available at: https://www.who.int/dg/speeches/detail/who-directorgeneral-s-opening-remarks-at-the-media-briefing-on-c ovid-19-11-march-2020.
4. WHO Coronavirus Disease (COVID-19) Dashboard Data last updated: 2021/2/8, Avaliable at: https:// covid19. who.int/?gclid=EAIaIQobChMIxun_jeLb7gIVjA VyCh2iMQKIEAAYASAAEgJeQvD_BwE

5. Munster VJ, Koopmans M, van Doremalen N, van Riel $D$, de Wit E. A novel coronavirus emerging in China-key questions for impact assessment. $N$ Engl $\mathrm{J}$ Med 2020;382:692-694. doi:10.1056/NEJMp2000929.

6. Velavan TP, Meyer CG. The Covid-19 epidemic. Trop Med Int Health 2020;25:278-280. doi:10.1111/tmi.13383.

7. Ayittey FK, Ayittey MK, Chiwero NB, Kamasah JS, Dzuvor C. Economic impacts of Wuhan 2019-nCoV on China and the world. J Med Virol 2020;92:473-475. doi:10.1002/jmv. 25706 .

8. Impact of COVID-19 on people's livelihoods, their health and our food systems. Joint statement by ILO, FAO, IFAD and WHO, 13 October 2020.

9. Qiu H, Tong Z, Ma P, Hu M, Peng Z, Wu W, Du B, China Critical Care Clinical Trials Group (CCCCTG). Intensive care during the coronavirus epidemic. Intensive Care Med 2020;46:576-578. doi:10.1007/s00134-020-05966-y.

10. WHO. 2020. Coronavirus disease 2019 (COVID-19) situation report-114 (13th May, 2020). https://www. who.int/docs/default-source/coronaviruse/situation-re ports/20200513-covid-19-sitrep-114.pdf?sfvrsn=17eb bbe_4. Accessed on 13 May 2020.

11. Lu H. Drug treatment options for the 2019-new coronavirus (2019-nCoV). Biosci Trends 2020;14:69-71. doi:10.5582/bst.2020.01020.

12. Sheahan TP, Sims AC, Leist SR, Schäfer A, Won J, Brown $A J$, et al. Comparative the rapeutic efficacy of remdesivir and combination lopinavir, ritonavir, and interferon beta against MERS-CoV. Nat Commun 2020;11:222. doi:10.1038/s41467-019-13940-6.

13. Pillaiyar T, Meenakshisundaram S, Manickam M. Recent discovery and development of inhibitors targeting coronaviruses. Drug Discov Today 2020;25:668-688. doi: $10.1016 /$ j.drudis.2020.01.015.

14. Cyranoski D. This scientist hopes to test coronavirus drugs on animals in locked-down Wuhan. Nature 2020;577:607. doi:10.1038/d41586-020-00190-6.

15. DhamaK, Pawaiya RVS, Chakrabort S, Tiwari R, Saminathan M, Verma AK. Coronavirus infection in equines: a review. Asian J Anim Vet Adv 2014; 9:164-176. doi:10.3923/ajava.2014.164.176.

16. Zaher NH, Mostafa MI, Altaher AY. Design, synthesis and molecular docking of novel triazole derivatives 
as potential CoV helicase inhibitors. Acta Pharm 2020;70:145-159. doi:10.2478/acph-2020-0024.

17. Kluge HNP. Statement - physical and mental health key to resilience during COVID-19 pandemic.

18. Gralinski LE, Menachery VD. Return of the coronavirus: 2019-nCoV. Viruses 2020;12:135.doi:10.3390/ v12020135

19. Fan Y, Zhao K, Shi ZL, Zhou P. 2019. Bat coronaviruses in China. Viruses 11:210. doi:10.3390/v11030210.

20. Lu R, Zhao X, Li J, Niu P, Yang B, Wu H, et al. Genomic characterization and epidemiology of 2019 novel coronavirus: implications for virus origins and receptor binding. Lancet 2020;395:565-574. doi:10.1016/S0140-6736(20)30251-8.

21. Benvenuto D, Giovanetti $M$, Salemi $M$, Prosperi M, De Flora C Jr, Alcantara LC, et al. The global spread of 2019-nCoV: a molecular evolutionary analysis. Pathog Glob Health 2020;114:64-67. doi: $10.1080 / 20477724.2020 .1725339$.

22. Bonilla-Aldana DK, Holguin-Rivera $Y$, Cortes-Bonilla I, Cardona-Trujillo MC, García-Barco A, BedoyaArias HA, Rabaan AA et al. 6 February 2020. Coronavirus infections reported by ProMED, February 2000-January 2020. Travel Med Infect Dis doi:10.1016/j.tmaid.2020.101575.

23. Zhang L, Shen FM, Chen F, Lin Z. 3 February 2020. Origin and evolution of the 2019 novel coronavirus. Clin Infect Dis doi:10.1093/cid/ciaa112.

24. Mahase E. China coronavirus: what do we know so far? BMJ 2020;368:m308. doi:10.1136/bmj.m308.

25. Hui DS, I Azhar E, Madani TA, Ntoumi F, Kock R, Dar O, et al. The continuing 2019-nCoV epidemic threat of novel coronaviruses to global health-the latest 2019 novel coronavirus outbreak in Wuhan, China. Int J Infect Dis 2020;91:264-266. doi:10.1016/j.ijid.2020.01.009.

26. Lu H, Stratton CW, Tang YW. Outbreak of pneumonia of unknown etiology in Wuhan China: the mystery and the miracle. J Med Virol 2020;92:401-402. doi:10.1002/jmv.25678.

27. Guan Y, Zheng BJ, He YQ, Liu XL, Zhuang ZX, Cheung $\mathrm{CL}$ et al. Isolation and characterization of viruses related to the SARS coronavirus from animals in southern China. Science 2003;302:276-278. doi:10.1126/science.1087139.

28. Monchatre-Leroy E, Boue F, Boucher JM, Renault C, Moutou F, ArGouilh M, Umhang G. Identification of alpha and beta coronavirus in wildlife species in France: bats, rodents, rabbits, and hedgehogs. Viruses 2017;9:364. doi: $10.3390 / v 9120364$

29. Knowles G. 2020. Will they ever learn? Chinese markets are still selling bats and slaughtering rabbits on blood-soaked floors as Beijing celebrates "victory" over the coronavirus. https://www.dailymail. co.uk/news/article-8163761/Chinese-markets-sellingbats.html.

30. Akarsh HP. 2020. Wuhan virus: Chinese animal markets reopened with almost no precautions. https://metrosaga.com/wuhan-virus-chinese-animalmarkets-reopened-with-almost-no-precautions/.

31. Blakeman BA. 2020. China must close down "wet markets" now. https://thehill.com/opinion/ international /490528-china-must-close-down-wet-markets-now.

32. Rodriguez-Morales AJ, Bonilla-Aldana DK, Balbin-Ramon GJ, Rabaan AA, Sah R, Paniz-MondolfiA et al. History is repeating itself: probable zoonotic spillover as the cause of the 2019 novel coronavirus epidemic. Infez Med 2020;28:3-5.

33. Pronker ES, Weenen TC, Commandeur H, Claassen EHJHM, Osterhaus ADME. Risk in Vaccine Research and Development Quantified. PLOS ONE. 2013;8:e57755. doi: $10.1371 /$ journal.pone.0057755.

34. London School of Hygiene \& Tropical Medicine COVID-19 Vaccine Development Pipeline. (2020). Available online at: https://vac-Ishtm.shinyapps.io/ ncov_vaccine_landscape/(accessed August 25, 2020).

35. Graham RL, Donaldson EF, Baric RS. A decade after SARS: strategies for controlling emerging coronaviruses. Nat Rev Microbiol 2013;11:836-848. doi: $10.1038 /$ nrmicro3143.

36. Cheng VCC, Wong SC, To KKW, Ho PL, Yuen KY. Preparedness and proactive infection control measures against the emerging Wuhan coronavirus pneumonia in China. J Hosp Infect 2020; 104:254-255. doi:10.1016/j.jhin.2020.01.010.

37. Pandemic. Wikipedia" https://en.wikipedia.org/wiki/ Pandemic, Accessed on 08/17/2020

38. Helal MSA, Bhuiyan MEM, Ahmed I. Virus and Covid19 Spread: In The Light Of Holy Quran And Hadith. ISSN 2515-8260. European Journal of Molecular \& Clinical Medicine 7(03):2020. 